\title{
PROTECTING NON-MUSLIM: ITS IMPLEMENTATION DURING EARLY MUSLIM RULE OF ISLAMICJERUSALEM
}

\author{
By: \\ Mohd Roslan Mohd Nor*
}

\begin{abstract}
Islamicjerusalem is a region of a great significant and has been given blessing (barakah) to all nations (li al-'älaminn). This barakah is not only for Muslims exclusively, but it is for all nations in this world, including to those Christians and Jews for their attention to the region. This is not only stated in the Quran, but most importantly it has been shown to the world during the Muslims rule over the region. This means that Muslims respect others and appreciate co-existence. It is interesting to note that the Quranic frameworks on eliminating racism, promoting equality and assurance of freedom and rights is being implemented since early days of Islam as can be noted in the case of Islamicjerusalem. When 'Umar came to Islamicjerusalem, he has granted rights to the people, regardless of their races, beliefs and ideological differences. What was more important is to bring peace together within the society. Only then the people were able to live together and prosperity of civilization is guaranteed. This paper attempts to explore Quranic framework in dealing with this matter and link its implementation in Islamicjerusalem region during the early period of Islam.
\end{abstract}

Lecturer in Department of Islamic History and Civilization, Academy of Islamic Studies, University of Malaya, Kuala Lumpur, Malaysia. Tel: +60379676008 Email: m_roslan@um.edu.my. 


\section{Introduction}

Throughout the history of Islam, Islamicjerusalem emerged as one of the important regions that have been given attention by Muslims. There are many reasons why Muslims are so attached with Islamicjerusalem. Being it because of religious reason or historical, it is in a central focus of Muslims. Nowadays, it becomes more central because of the political situation and conflict, and it is a world focus.

Islamicjerusalem has gone through different rule until today. As a result, the region is rich with history and notably it has culture diversity during Muslims rule. One may noted that when it became under Muslims, the landscape changed, from the exclusive region to inclusive and people started respect co-existence. When Islam came to the region, Islamicjerusalem became a safe place to all people. It is not an easy transformation and remarkably it happened when Muslims rule the region.

To further the discussion, this paper thus will attempt to discuss relevant points of safety and freedom assurance given to the inhabitants of Islamicjerusalem during Muslims rule over the region. It is first will explore and relate this concept to Quranic framework on this matter, as it is one of the two core sources for Muslims in all areas of their life including how to deal with others.

\section{Quranic Guidelines On Protecting Rights}

There are a lot of Quranic verses mentioned about dealing with others including non-Muslims. One could argue that there are harsh verses towards non-Muslims, but only if these are taken in different context and wrong place. However, what struck most are the verses that allow Muslims to work together with non-Muslims, ask Muslims to deal in a good manner and not to harm others.

To interpret Muslim history, one needs to look at the core sources in Islam (Quran and Hadith), and it is vice versa. History plays an important role in Quran and Hadith interpretation. Without which, one cannot get comprehensive understanding on the two core sources in Islam, as well as history. So, these are interrelated each other and cannot be purposely separated. 
Although one may take verses from Quran and use in different context to create more tension to non-Muslims, academics and scholars should avoid this to happen. People also need to be careful when taking any information which intentionally or not being related to Islam, because any misinformation will not do any good to the society. That is why in the Quran, there is a verse clearly asked people to verify information they received. The word 'tabayyanu' has been used to double check and make sure that information received is correct, not a spin or false assumption.

Quran guides Muslims that they should be mercy to others. This is in fact one of the attributes of the Prophet Muhammad (p.b.u.h). It is clearly stated in the Quran: "And We have not sent you but as a mercy to the worlds" Sürah al-Anbiyā' (21):107. Prophet Muhammad, the beloved Messenger of Allah, who was sent as a mercy for the whole of mankind, demonstrated such kindness, compassion, generosity and politeness towards non-Muslims that it is difficult to find similar examples in history. ${ }^{1}$

In other verses, Allah says:

"Thus it is due to mercy from Allah that you deal with them gently, and had you been rough, hard hearted, they would certainly have dispersed from around you; pardon them therefore and ask pardon for them, and take counsel with them in the affair; so when you have decided, then place your trust in

\footnotetext{
When Makkah was in the grip of famine, he personally went out to help his enemies who had made him leave his home town. At the conquest of Makkah, all his enemies came under his power and control, yet he set them all free saying that not only are you being given amnesty today but rather you are also forgiven for what you have done in the past. When non-Muslim prisoners of war were presented before him, he treated them with such kindness and tenderness as one would treat his own children. His enemies inflicted upon him all sorts of injuries and pain but he never raised his hand in revenge neither did he wish ill for them, rather he would pray for their guidance. A delegation from the tribe of Banū Thaqĩfah (who had yet not accepted Islam) came to visit him, and was given the honour of staying in the Mosque of the Prophet, a place regarded by Muslims to be the most sacred of places.
} 
Allah; surely Allah loves those who trust"

Sūrah Āli-'Imrān (3):159.

"O you who believe! Stand out firmly for Allah, as witnesses to fair dealing, and let not the hatred of others to you make you swerve to wrong and depart from justice. Be just: that is next to piety: and fear Allah. For Allah is well-acquainted with all that you do."

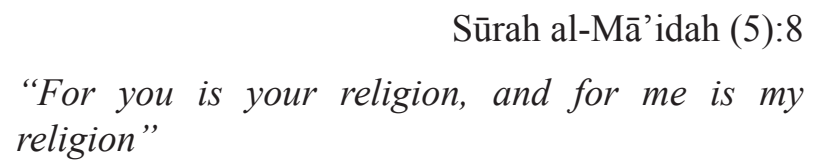
religion"

Sūrah Al-Kāfirūn (109):6

The above verses clearly stated that Muslims need to treat nonMuslims justly and honourably. Muslims also need to guarantee freedom of others as can be understood from Sūrah al-Kāfirūn. The dislike of their beliefs should not prompt a Muslim to treat them unfairly. If one was to look at the various texts of the Qur' an with regards to interaction and communication with non-Muslims, this aspect of mercy, justice and moderation would become even more manifest and clear.

From its early days, Islam shows the necessity to protect rights of people. For Muslims, this is encompassed in what is known as Maqāsid al-Sharī'ah. There are five essential values that Islam seeks to protect and which thus form an integral part of the Maqāsid alShari' 'ah, are religion, life, intellect, family (nasab) and property, were all fundamentally elucidated in the Makkan portions of the Qur'an. ${ }^{2}$ This means before the Madinah period, where Islam starts expanding and reaching out of Arabian Peninsula, the protection of rights has been established. Thus, it is clear that the vision of safety, respecting others, equal rights and freedom has started and established since early days of Islam which manifest in territories control by Muslims including of Islamicjerusalem.

Al-Raysuni, A. (2006). Imam Al-Shātibī's Theory of the Higher Objectives and Intents of Islamic Law, Kuala Lumpur: Islamic Book Trust, p.137. 
According to Maher Abu-Munshar, "despite the substantial number of scholarly works and news stories to the contrary, many people still have the unfortunate misconception that Muslims cannot tolerate, coexist, or cooperate with followers of other religions. This is partly because Muslim extremists themselves often (mis)use Qur'anic verses to justify acts of violence against non-Muslims. Simply put, these interpretations are wrong. In fact, many verses in the Qur'an call for friendship, fair treatment and cooperation with non-Muslims but are ignored by those wishing to create division in order to fan the flames, so to speak." ${ }^{3}$

\section{Islamicjerusalem And Its Culture Diversity}

Armstrong argues that, "the Muslims had established a system that enabled Jews, Christians and Muslims to live in Jerusalem together for the first time." Abd al-Fattah El-Awaisi mentioned that it's fact that it was not long after the beginning of Muslim rule that Jews did settle in Islamicjerusalem again after 500 years of prohibition. These clearly indicate that the inhabitants of Islamicjerusalem comprise of at least 3 major religious backgrounds, Jews, Christians and Muslims. Thus, it can simply be noticed that the region comprise of culture diversity.

It is quite unbelievable to know that Muslims were not the majority inhabitants during the first Muslims conquest of Islamicjerusalem. This is according to Armstrong who argues that Christians remained in majority in Islamicjerusalem, while Muslims remained in minority until the Crusaders period. ${ }^{5}$ Although the majority was Christians, but when Islamicjerusalem became under Muslims for the first time, it became an inclusive region, which includes people of various background, race and religion. According to Armstrong, Umar was "faithful to the Islamic inclusive vision. Unlike the Jews and Christians, Muslims did

3 Maher Y Abu-Munshar, "Settling the 'infidels' Questions in Islam," 1 December 2009. http://www.commongroundnews.org/article. php?id=26868\&lan=en\&sp=0, accessed on 3 March 2011.

4 Karen Armstrong (1997a). A History of Jerusalem: One City Three Faiths. London: Harper Collins Publishers, p. 246.

5 Karen Armstrong (1997b). 'Sacred Space: The Holiness of Islamic Jerusalem,' Journal of Islamic Jerusalem Studies. Winter, Vol. 1, No. 1, UK: Islamic Research Academy, pp. 14-15. 
not attempt to exclude others from Jerusalem's holiness" 6

This has later on supported by, Abd al-Fattah El-Awaisi who argues, "Muslims have made Islamic Jerusalem an inclusive region, which opened to all traditions, backgrounds and cultures to live together in peace." This could mean that Muslims has eliminated racism and at the same time promote equal rights of living together.

In another point of view, Muslims demonstrate that they respect diversity and those who inhabit Islamicjerusalem by using the same name to call the region, the name that has been used before it was conquest. The name Aelia, referring to the region, was not been changed immediately, although Prophet Muhammad used this name and other names too in his Hadith. During the first conquest of Islamicjerusalem by Muslims, Umar still use the word Aelia. Al-Tabarī has recorded that Umar "has granted to the people of Aelia..." This indicates clearly that Umar used the name Aelia, to address the people of that region and did not change it with any other term. El-Awaisi quotes Armstrong argument that it was a common practice performed by Rightly-Guided Caliphs as they simply endorse existing arrangements. ${ }^{9}$ This means the act of respect was there.

The same positive attitude has been shown with regard to the coinage minted during early days of Islamicjerusalem under Muslims rule. It appears that immediately following the Muslims conquest; the first coins struck in Islamicjerusalem were inscribed in Greek only, as this was the known language among the residents of Islamicjerusalem. In these coins, as in those dating from the Heraclian period (610-717

$6 \quad$ Ibid., p. 14.

7 Abd al-Fattah El-Awaisi (2003). Exploring Identity of Islamic Jerusalem, unpublished, p. 3. This paper is presented during the $5^{\text {th }}$ International Academic Conference on Islamic Jerusalem 2003 at Sheikh Rashid Conference Hall, Al-Maktoum Institute for Arabic and Islamic Studies, Dundee, UK.

8 Abū Ja'far Muḥammad ibn Jarīr Al-Ṭabarī (1999). Tārīkh al-Ṭabarī,Tārīkh al-Umam wa al-Muluk. Beirut: Dār al-Kutub al-'llmiyyah, Vol. 2, p. 449.

9 Abd al-Fattah El-Awaisi (2000). 'Umar's Assurance of Safety to the People of Aelia: A Critical Analytical Study of the Historical Sources. Journal of Islamic Jerusalem Studies. UK: Islamic Research Academy, Summer, vol. 3, no. 2, p.56. 
AD), the name of the region is the ancient Greek name referring to Islamicjerusalem, IEPOCO $\mathrm{VMA} \cdot{ }^{10}$ In the Arabic inscriptions of the later coins, the name of the region minted as Aelia, which is a Latin form. This followed with an added expression, Filastin ${ }^{11}$ at the later stage, when stability has been established and assured.

These clearly show that Muslims respect others of diverse background and religions. The culture diversity does not mean that one should dominant over others but its more on respect, toleration and sincerity.

\section{Assurance Given To Inhabitants Of Islamicjerusalem}

Historically, it can be argued that Islamicjerusalem only turned into a safe region of multi-racial and multi-cultural when it was under Muslims rule. One may notice that before the first Muslims conquest, it was under catastrophe after it has been a subject of claimed and disputed by Roman Byzantine and Persian.

Armstrong gives a clear attitude of Muslims during the first conquest of Islamicjerusalem. She states that Umar:

"presided over the most peaceful and bloodless conquest that the city had yet seen in its long and often tragic history. Once the Christians had surrendered, there was no killing, no destruction of property, no burning of rival religious symbols, no expulsions and expropriations, and no attempt to force the inhabitants to embrace Islam. "'12

In order to achieve stability in multi- cultural and multi-racial society, it needs kind of 'social contract' or agreement between parties involved. However, it should not stop only by producing agreement,

10 Yaakov Meshorer (1996). 'Coins of Jerusalem Under The Umayyads and The Abbasids,' in Joshua Prawer and Haggai Ben-Shammai. The History of Jerusalem: The Early Muslim Period, 638-1099. New York and Jerusalem: New York University Press and Yad Izhak Ben-Zvi, p. 413.

11 Ibid. According to Meshorer, the name Filastin at one stage was referring also to the military district that includes Islamicjerusalem.

12 Karen Armstrong (1997a). op. cit., p. 228. 
but most importantly how these parties can abide with the rules and regulations stated in that document. Historically, Islam has shown that negotiation in producing agreement happened since its early era during the time of Prophet Muhammad (p.b.u.h). The obvious simple example is the 'constitution' of Madinah, known in Arabic as Șah̆ifah Madīnah or Dustūr Madīnah which was penned in $622 \mathrm{AD}$.

One may claim that Șahïfah Madinah is a well working model of guideline drawn in order to live together in multi-racial society. There are 47 items in this document, ${ }^{13}$ which among others may be simplified as below:

i. agreement of brotherhood between Muhäjirin (those migrated to Madinah from Makkah) and Anșār (Madinah people)

ii. the state of non-Muslim living in Islamic environment in Madinah

iii. public declaration that Madinah is a Muslim territory

iv. acknowledge that Quran and Hadith are two core sources in Islam

V. Prophet Muhammad is a head leader

vi. Cooperation of all people Muslim or non-Muslim to defend Madinah from enemies and outsiders attack

It should be noted that the other agreements or assurances towards non-Muslims have different concerns however they do not differ in major principles. What are these principles? From Șahĭfah Madinah, one may notice that the most key principles is to give assurance of safety to live in any particular territories governed by Muslims. This is in addition that so long they can abide with the rules and regulations outlined in the agreement, otherwise they would be driven out of these territories.

The fact that this kind of document exists, shows that Muslims should treat their non-Muslim fellows with kindness consideration and beneficence. In the situation that their non-Muslim fellows do not do any harm to them, thus they have to show a good manner. This is what

13 A. Guillaume (1955). The Life of Muhammad: A Translation of Ishaq's Sirat Rasul Allah. Karachi: Oxford University Press; pp. 231-233. 
has been mentioned in the Quran and Muslims need to follow this clear guideline from Allah. In the Quran, Allah says:

"Allah forbids you not, with regards to those who do not fight you for your faith, nor drive you out of your homes, that you should deal kindly (tabarruhum birr) and justly (tuqsitū - qist) with them."

Surah Al-Mumtahinah (60):8

The reality that this verse use the word 'birr' and 'qist! has clearly shows how the attitude of Muslims should be upon non-Muslims. The word 'birr' also been used in the Hadith to ask believers to deal kindly with their parents (birr al-wālidayn). In explaining this verse, Al-Ṭabarī (d. $310 \mathrm{H})$ says that it means you need to be just with your mercy upon them (non-Muslim). ${ }^{14}$ Meanwhile Al-Qurțubī (d. $671 \mathrm{H}$ ) gives more wider meaning by stating that this verse asks Muslims to be kind towards non-Muslims until they died, and to give some money to them in the face of relationship. (تعطوهم قسطاً من أموالكم على وجه الصلة).

In broader meaning and explaining what are the acts of birr, it is worth noting that the other verse has provided explanation. Allah says in the Quran:

"It is not al-birr (kindness / righteousness) that you turn your faces towards east and west (in prayers); but al-birr is (the quality of) the one who believes in Allah, the Last Day, the Angels, the Book, the Prophets and gives his wealth, in spite of love for it, to the kinsfolk, to the orphans, and to the poor (al-masākin) and to the wayfarer, and to those who ask, and to set slaves free, performs daily ritualistic prayer and gives the charity (for purification) and who fulfill their agreements when they make them, and who are persevering and steadfastly patient in extreme poverty and ailments and at the time of fighting in battles. Such are the people of truth and piety (al-muttaqūn)."

Sūrah al-Baqarah (2):177

14 See Al-Ṭabarī's exegesis on verse 8 of Sūrah al-Mumtahinah.

15 See Al-Qurțubī's exegesis on verse 8 of Sūrah al-Mumtahinah. 
From this verse, it is clear what al-birr means and what are the acts that considered al-birr. This include giving money to the people, and its not then unusual for al-Qurțubī, although its unique, to suggest that giving money to non-Muslims as parts of building relationship.

Hence, it is not unusual act for the Caliphs that followed after Prophet Muhammad death to follow the example of what has been in practiced during the time of Prophet. Although it was not exactly the same, but most of the general principles are being kept. For instance the way of dealing with others from different faiths and cultures, where someone need to be kind to others etc.

In this case, when Umar came to conquer Islamicjerusalem, he has given assurance of safety to the people in that region. The assurance known in Arabic as al-Uhdā al-Umariyyah, translated in English by Abd al-Fattah El-Awaisi as Umar Assurance of Safety to the People of Aelia. In fact, he has done extensive study on the assurance and it was published in the Journal of Islamic Jerusalem Studies. ${ }^{16}$ The assurance given is as follows:

"This is the assurance of safety which the servant of Allah, Umar, the Commander of the Faithful, has granted to the people of Aelia. He has granted them safety for their lives and possessions; their churches and crosses; the sick and the healthy of the city; and for the rest of its religious community. Their churches will not be inhabited nor destroyed. Neither they, nor the land on which they stand, nor their cross, nor their possessions will be confiscated. They will not be forcibly converted, nor any one of them harmed. No Jew will live with them in Aelia. The people of Aelia must pay the poll tax like the people of the [other] cities, and they must expel the Byzantines and the robbers." "As for those who will leave, their lives and possessions shall be safeguarded until they reach their place of safety; and as for those who remain, they will be safe. They will have to pay the poll tax like the people of Aelia. Those people of

16 Abd al-Fattah El-Awaisi (2000). op. cit., pp.75-78 
Aelia who would like to leave with the Byzantines, take their possessions, and abandon their churches and crosses will be safe until they reach their place of safety. Those villagers (ahlal-Ard) who were in Aelia before the killing of so-and-so may remain in the city if they wish, but they must pay the poll tax like the people of Aelia. Those who wish may go with the Byzantines, and those who wish may return to their families. Nothing will be taken from them until their harvest has been reaped. The contents of this assurance are under the covenant of Allah, are the responsibility of His Prophet, of the Caliphs, and of the Faithful. If [the people of Aelia] pay the poll tax according to their obligations. The persons who attest to it are: Khālid Ibn al-Walìd, 'Amr Ibn al-'As, 'Abd al-Rahmān Ibn 'Awf, and Mu'awiyah Ibn Abī Sufyān. This assurance was written and prepared in the year 15 [A.H.]" (636AD)

Apparently, this assurance was given about 14 years after the Șahiffah Madinah. So, its general principle of safety and freedom were included. By giving this assurance, the community felt safe to live and socialise with others. More particularly, Umar gave a formal assurance to respect the Christian churches and the security of its inhabitants. ${ }^{17}$ This is not strange because the majority of inhabitants were Christians, however to give such clear and strong statement indicate that Muslims able to provide freedom and able to tolerate with others of different race and most noticeably of different belief.

Nevertheless, there is a controversial sentence within this assurance, which is: No Jews will live with them in Aelia. Some of the western scholars have thrown their doubt on the authenticity of the document. Some argue that the document has been prepared at the later stage, not during the Caliph Umar time, but it is attributed to Caliph Umar in order to get greater authority and respect from people. ${ }^{18}$ Nevertheless

\footnotetext{
17 Henry Cattan (1973). Palestine and International Law. London: Longman Group Ltd, p. 10.

18 A. S. Tritton (1970). The Caliphs and their non-Muslim Subjects: a Critical Study of the Covenant of 'Umar. London: Frank Cass.
} 
this argument is merely a self-doubt, without any convincing supportive arguments.

This ex clusion of Jews is according to Abd al-Fattah El-Awaisi was the result of what Emperor Hadrian had done to the Jews, since 139 $\mathrm{AD}$ forbidding the Jews to enter the region, live there, come near it or even look at it from afar. This is later on contrast with the report that there were about 70 Jewish families moved to the region. ${ }^{19}$ Then, Gil states that "... Jews from all over the worlds come to pray and study in Jerusalem." $" 20$

Abd al-Fattah El-Awaisi argues that the versions of Umar's Assurance has been expanded and embroidered concludes by saying: "As for additions and conditions (expel the Jews from residing in Aelia) attributed to Umar Ibn al-Khațtāb, they are the product of later historical periods, resulting from socio-political circumstances that differed greatly from the time of the first Islamic conquest of Jerusalem."21

History witnessed that Muslims came to conquest Islamicjerusalem in a peaceful manner. In fact the conquest did not involve any mass immigration of the Arabs from the Arabian Peninsula into Palestine as a whole. The number of Muslim armies was very small and they were assimilated by the indigenous population. ${ }^{22}$ As a result of this assimilation of diverse racial and cultural, many of the inhabitants converted to Islam which "predominantly Christian population became predominantly Muslim". ${ }^{23}$ Although many became Muslims, the rest who chose to remain in their religion did not leave the region and no one had been force to leave. They remain in the region even after the conquest. This is definitely because the inhabitants felt safe under Muslims rule which they hardly to resist or throw the new ruler of Islamicjerusalem.

The practice of Umar did not last at his time only, but it was followed by Salahudin who captured Islamicjerusalem for the second

\footnotetext{
19 Moshe Gil (1997). A History of Palestine 634-1099. UK: Cambridge University Press, p. 167.

$20 \quad$ Ibid., pp. $165-166$.

21 Abd al-Fattah El-Awaisi (2000). op. cit., pp.75-78.

22 Ibid.

23 Ibid. See also Encyclopaedia Britannica, 1966, Vol. 17, p. 166.
} 
time by Muslims. Cattan may provide a clear account on this matter, by stating that:

"on the two occasions when the Arabs captured Jerusalem, first in AD 637 and again in AD 1187, they did not indulge in any massacre of the indeginious population or undertake its displacement. We have noted that when Jerusalem surrendered to Caliph Omar, he gave a pledge, which was kept, for the security of its inhabitants. Similarly, when Saladin captured the city from the Crusaders, the inhabitants were spared. Christians of alien or Frankish origin, as they were called, gained their freedom by means of the payment of a ransom and were allowed to leave for Syria, where the Crusaders possessed some territories. As for the indeginous Christians, they were allowed to remain in the city but were subjected to the payment of the jizya or head tax. This conduct on the part of the Arabs contrasts with the massacre of the Christians of Jerusalem by the Jews and the Persians in AD 614, and with the massacre of both Moslems and Jews by the Crusaders on their capture of the city in AD 1099." 24

Therefore, it becomes apparent that from the first Muslims conquest of Islamicjerusalem, and when the region under Muslims control, the region was experiencing good intra-relation between inhabitants. It also flourishes with activities, religiously or socially. This continues until the region once again fall out from Muslims hand in this recent era.

\section{Conclusion}

From the above discussion, it can be concluded that Islamicjerusalem during Muslims rule has shown the effort to eliminate racism, promoting equality and freedom by producing assurance document to the people. Although there were various background of people, but they were given safety assurance for the life, freedom in their religious and social activities. Living in multi-racial society is not simple. Thus, it is

24 Henry Cattan (1973). op. cit., p.11. 
fascinating to read a recent statement commented by ex-Prime Minister of Malaysia, Dr. Mahathir that "multi-racial countries are usually unstable. Racial conflicts occur frequently." ${ }^{25} \mathrm{He}$ may be right when taking this view from political context, but unfortunately this was not the case during early Muslims rule of Islamicjerusalem. This could be the result of assurance given to inhabitants of the region as early as it was under the authority of Muslims. Hence, assurance document has played a major role to ensure the stability in spite of safety, equality and freedom within the multi-cultural, multi-racial and multi-religious society.

25 Tun Dr. Mahathir Mohamed, Multi-racial Malaysia. http://www.chedet. com/2008/06/multi-racial-malaysia.html. Accessed on 4 June 2008. 